\title{
Courtship Behavior in the Cuban Ameiva (Ameiva auberi ustulata, Squamata: Teiidae) from the Siboney-Juticí Ecological Reserve in Eastern Cuba
}

\author{
Yasel U. Alfonso ${ }^{1}$ and Javier Torres ${ }^{2}$ \\ ${ }^{1}$ Centro de Aplicaciones Tecnológicas para el Desarrollo Sostenible (CATEDES/CITMA) I, \\ Agramonte No. 818 e/ Aguilera y Prado, Guantánamo, CP 95100, Cuba (anoles1983cuba@gmail.com) \\ ${ }^{2}$ Departamento de Biología Animal y Humana, Facultad de Biología, Universidad de la Habana, \\ Calle 25 \# 455 e/ J e I, Vedado, Plaza de la Revolución, La Habana, CP 10400, Cuba (jtorres@fbio.uh.cu)
}

\begin{abstract}
The genus Ameiva Meyer 1795 comprises 23 species of which 14 are found in Central and South America and 18 occur in the West Indies. These lizards occupy diverse habitats (e.g., grasslands, tropical forests, sandy beaches) but most species appear to prefer open areas. They are ground-dwellers and active diurnal foragers. Cuba harbors only one species, Ameiva auberi. However, 40 subspecies are distributed widely across the main island, adjacent cays, and on into the Bahamas. Reproductive behavior has been documented in some species in the family Teiidae, but not for $A$. auberi, about which only one published account reported the underground deposition of a single egg. Herein, we describe for the first time the reproductive behavior (except ovipositioning) of $A$. auberi ustulata in natural habitat in the Ecological Reserve Siboney-Juticí (eastern Cuba) on 22-25 July 2009. Between 1200 and 1600 h, we observed six mating pairs directly or while using monocular Nikon Fieldscopes. We describe three sequential stages of reproductive behavior: (1) Pursuit, (2) premating and mating, and (3) excavation, with a total duration of $64.8 \pm 17.6 \mathrm{~min}$ (46-92 $\mathrm{min}$ ).
\end{abstract}

T he family Teiidae Gray 1827, with a distribution limited to the Western Hemisphere, contains nine genera (Hower and Hedges 2003). One of these, the genus Ameiva Meyer 1795, includes 32 species, of which 14 occur in Central and South America and the remaining 18 in the West Indies. These species occupy diverse habitats, including grasslands, tropical forests, and sandy beaches (Schwartz and Henderson 1991, Hower and Hedges 2003, Henderson and Powell 2009), where most West Indian species appear to prefer open areas. These lizards are generally characterized as terrestrial diurnally active foragers (e.g., Schwartz and Henderson 1991, Sproston et al. 1999, Henderson and Powell 2009), although a few individuals of some species have been observed ascending tree trunks in search of prey (Powell and Censky 2002).

Despite the diversity and abundance of these lizards little is known about their natural history, particularly reproduction. Reproductive behavior has been described in other species in the genus Ameiva, including A. ameiva (Simmons 1975, Quesnel 1978, Costa et al. 2010), A. chrysolaema (Noble and Teale 1930), A. quadrilineata (Hirth 1963,
Smith 1968), A. festiva (Smith 1968), A. fuscata (Somma and Brooks 1976), A. pleii (Censky 1995a, 1995b), and A. exsul (Lewis 1986, Rodríguez-Ramirez and Lewis 1991, Lewis et al. 2000).

The Cuban Ameiva (Ameiva auberi Cocteau 1838) contains 40 currently recognized subspecies. Twenty-eight of these are widely distributed across the Cuban archipelago, including a number of tiny cays (Gali and Garrido 1986, Rodríguez 2000). The only aspect of the species' reproductive biology to have been described is a single instance of ovideposition (Estrada et al. 1987). Herein we describe for the first time courtship behavior in six mating pairs of Ameiva auberi ustulata Schwartz 1970 in their natural habitat.

\section{Materials and Methods}

We conducted fieldwork on 22-25 July 2009 in the Ecological Reserve Siboney-Juticí, Santiago de Cuba (Fig. 1), where Ameiva auberi ustulata is abundant (Fong et al. 2005). Pairs were observed directly or using a monocular Nikon Fieldscope. Observations occurred between 1200 and $1600 \mathrm{~h}$ 


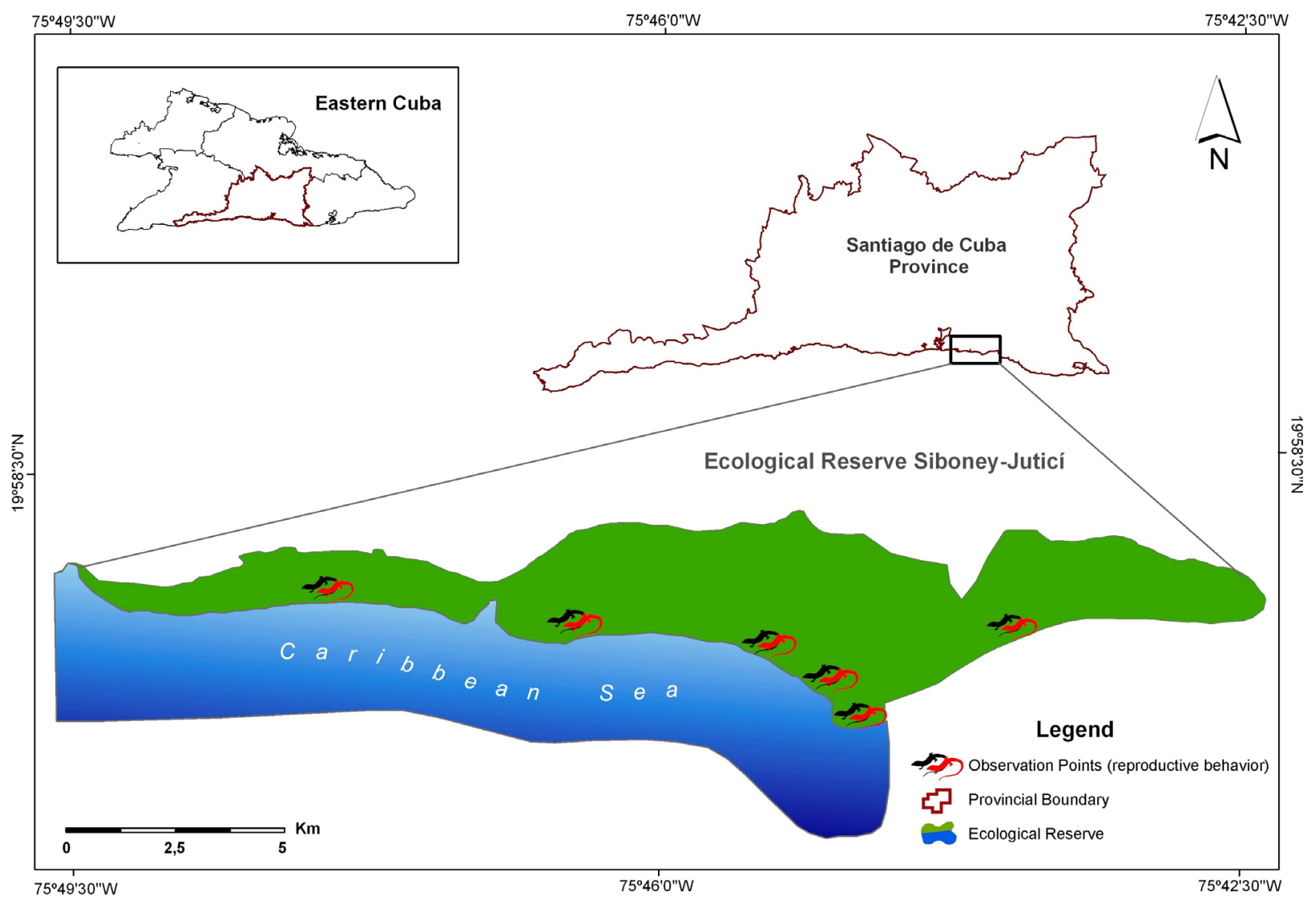

Figure 1. Locations of observations of mating Ameiva auberi ustulata in the Ecological Reserve Siboney-Juticí, Santiago de Cuba, Cuba.

and were made from distances of 5.7-21.4 $\mathrm{m}(15.8 \pm 5.8 \mathrm{~m})$. We measured the duration of each stage with a digital chronometer (rounded to the nearest $0.1 \mathrm{~s}$ ). Means are presented \pm one standard deviation.

\section{Results}

We observed six copulating pairs, for which we described three behavioral stages: (1) pursuit, (2) premating and mating, and (3) excavation. Pursuit lasted $32.0 \pm 4.0 \mathrm{~min}$ (27.6$37.4 \mathrm{~min}$ ). Males actively pursue females and might engage with other males competing for the same female. Some male aggression might be directed at the potential mate. During these engagements, a large and apparently dominant male bites or attacks other nearby males, often chasing them considerable distances before returning to the female. Once other males are dispersed, the winner initiates actual courtship by closely following the female along a serpentine trajectory (Figs. 2A \& 3C), often panting (more frequent ventilation than usual with evident expansion of the gular region). Tongue-flicking rates increase in both individuals, with the male frequently licking the back and sides of the female.

The second stage (premating and mating) lasted $3.5 \pm$ $1.1 \mathrm{~min}(2.3-5.5 \mathrm{~min})$. Males immobilize a female by biting a hindlimb and twisting until achieving penetration from the side opposite the bitten limb, in effect forming a horseshoe, the ends of which are the head and vent of the male (Fig. 2B). Subsequent separation (Fig. 2C) is quick and abrupt, with individuals often separating by $>50 \mathrm{~cm}$.

Excavation lasted $26.5 \pm 17.4 \mathrm{~min}(12.7-53.4 \mathrm{~min})$ and entailed both individuals digging a hole with a diameter of $-2 \mathrm{~cm}$ and a depth to as much as $28 \mathrm{~cm}$ (Figs. 2D-E). Both lizards repeatedly entered and left the hole until excavation was concluded (Fig. 2F). Entire episodes lasted $64.8 \pm 17.6$ $\min (46-92 \mathrm{~min})$.

\section{Discussion}

All of our observations of mating occurred from 1200-1600 h. Sampedro et al. (1982) indicated that the activity period for this species is $900-1600 \mathrm{~h}$, with a peak at $1100-1200 \mathrm{~h}$. Activity periods for other West Indian species of Ameiva are unimodal or bimodal, usually with peaks in both instances at mid- to late morning (Henderson and Powell 2009).

These observations of mating behavior in $A$. auberi ustulata in late July might be timed so hatchlings emerge during the late-summer/fall rainy season, when resources presumably are most abundant. Although not known for Cuban A. auberi, Smith's (1968) study of reproductive activity in Costa Rican A. festiva and A. quadrilineata indicated that ovi- 

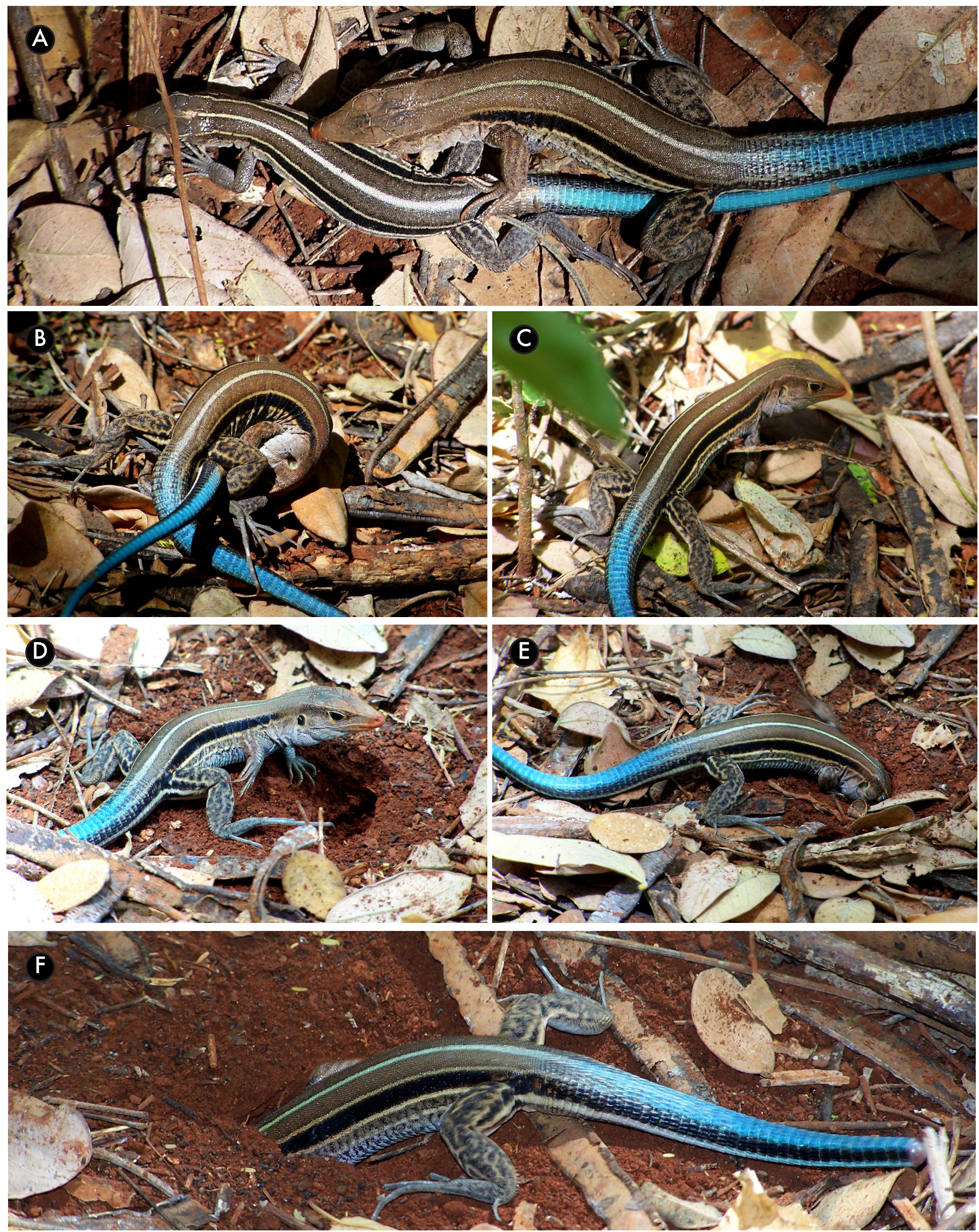

Figure 2. Courtship behavior in Ameiva auberi ustulata: A. premating, the male is in a superior position; B. copulation; C. separation; D-E. excavation; F. the female is in the hole the male is entering. 
positioning occurs 17-21 days after ovulation. We did not observe hatchlings nor see any signs of actual ovipositioning during the sampling period. Copulating $A$. ameiva tobagana on Grenada (Simmons et al. 2005) and A. erythrocephala on St. Eustatius (Kerr et al. 2005) were observed in June. Meier et al. (1993) observed $A$. polops on Green Cay (St. Croix) mating in August.

Quesnel (1978) described a four-stage courtship based on observation of 19 pairs of $A$. ameiva tobagana in their natural habitat. The first three stages (summarized in Fig. 3A) involve male behavior prior to mating. During this time, a male circles a female that occasionally moves more slowly to allow the male to approach. These circular movements are repeated with increasingly smaller diameters until mating occurs. For A. auberi ustulata, we combine all pre-mating behaviors into a single category (pursuit). Pairs do not engage in the circular movements seen in $A$. ameiva tobagana. Instead, male movements parallel those of the female and tend to follow a serpentine path (Fig. 3C).

The fourth stage described by Quesnel (1978) corresponds to the second stage we describe in the courtship of $A$. auberi ustulata. However, relative position and posture vary. In both instances, males are on top of the females, but male $A$. ameiva tobagana are diagonal or almost perpendicular relative to the female (Fig. 3B), whereas male A. auberi ustulata curl around the female (Fig. 3D), similar to what Noble and Teale (1930) described for $A$. chrysolaema. Copulatory duration of the two species was almost identical $(2.01 \pm 0.3 \mathrm{~min}$ in $A$. ameiva tobagana and $2.03 \pm 0.25 \mathrm{~min}$ in $A$. auberi ustulata). This relatively short time might serve to minimize exposure to predators at a time when lizards are particularly vulnerable. Lima and Dill (1990) noted that reproductive activities can expose both sexes of certain taxa to increased risk of predation, but Cooper (1999) indicated that the benefits of repro-

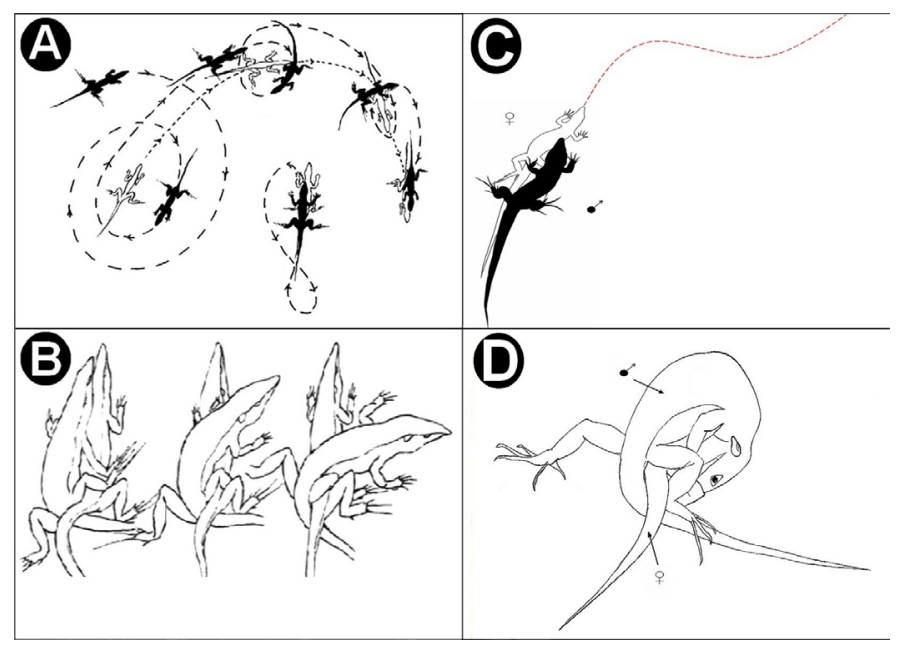

Figure 3. Courtship (A) and mating (B) in Ameiva ameiva tobagana (from Quesnel 1978); pursuit (C) and copulation (D) in A. auberi ustulata (this study).

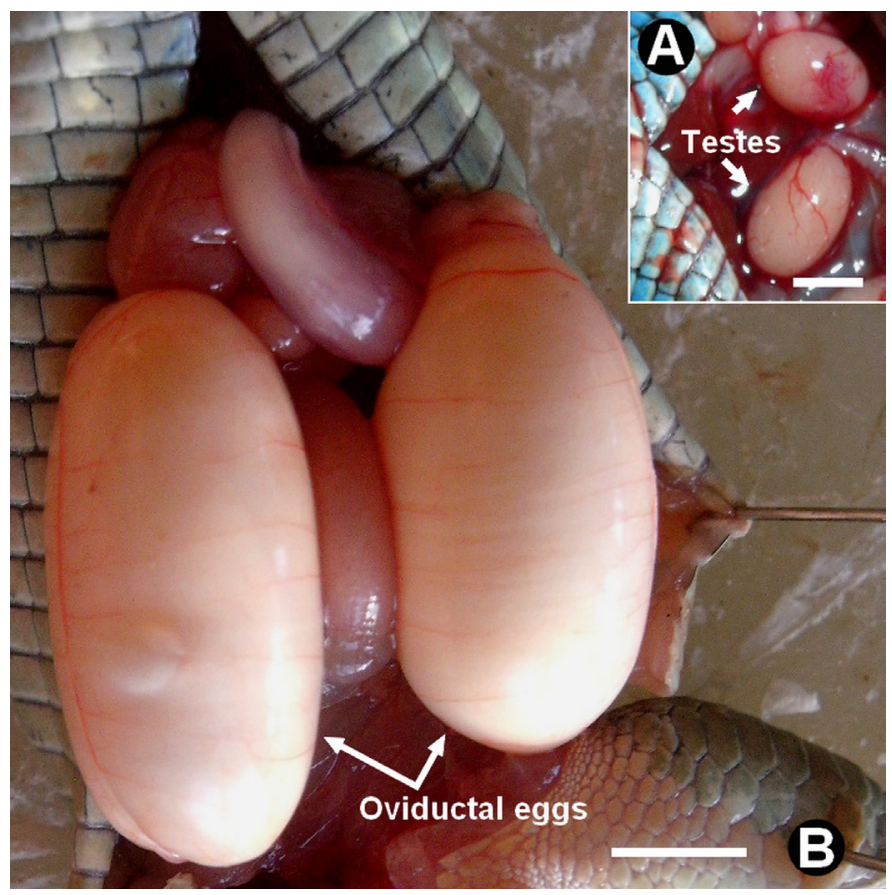

Figure 4. Macroscopic aspect of the reproductive systems in (A) a mature male $(S V L=62.5 \mathrm{~mm})$ and $(\mathrm{B})$ a mature female $(S V L=60.8 \mathrm{~mm})$ Ameiva auberi hardyi in the Parque Nacional Desembarco del Granma, Granma, Cuba. White bar $=5 \mathrm{~mm}$.

ductive success in many instances offset the costs of increased exposure to predators.

The third stage (excavation) has not been reported for other species of Ameiva or for other subspecies of A. auberi. At this time, females are not gravid or ready to lay eggs, but the hole might be used for ovipositioning at a later date if ovipositioning behavior of $A$. auberi ustulata is similar to that of Saw-scaled Curlytails (Leiocephalus carinatus: Leiocephalidae), another diurnally active terrestrial lizard known to occur in the Ecological Reserve Siboney-Juticí. Eggs of the latter species are deposited in holes dug previously and carefully covered and camouflaged with dirt and surface debris (unpubl. data).

The only data on eggs of A. auberi (Estrada et al. 1987) are from a single white, ovoid egg buried in a semideciduous forest over karst on the Peninsula of Guanacahabibes (western Cuba). That egg measured $11.8 \times 15.8 \mathrm{~mm}$, but recent (August 2011) observations in another subspecies from southeastern Cuba ( $A$. auberi hardyi) revealed two oviductal eggs that averaged $24.2 \mathrm{~mm}$ in length (Fig. 4). Additional oviductal eggs in earlier stages of development were also evident (unpubl. data). Even if clutch size is only one or two, females might lay multiple clutches during a reproductive season, as in A. exsul (Rodríguez-Ramirez and Lewis 1991) and A. pleii (Censky 1995b). Clutch size in A. fuscata is $5(\mathrm{~N}=1$; A. James in Henderson and Powell 2009), whereas clutch size is 1-7 in Anguillian A. pleii (Censky 1995a) and in Puerto Rican A. exsul (Wolcott 1923, Lewis 1986, Rodríguez-Ramirez and Lewis 1991) and A. wetmorei (Rodríguez-Ramirez and Lewis 
1991), with eggs measuring $20-22 \times 13-15.5 \mathrm{~mm}$ in the latter species (Wolcott 1923).

\section{Acknowledgments}

We thank the personnel of the biological station at the Siboney-Juticí Ecological Reserve for their hospitality and assistance. Dr. O.H. Garrido provided helpful comments on an earlier draft of this manuscript. Robert Powell provided helpful literature, comments, and suggestions on an earlier draft of this manuscript.

\section{Literature Cited}

Censky, E.J. 1995a. Reproduction in two Lesser Antillean populations of Ameiva plei (Teiidae). Journal of Herpetology 29:553-560.

Censky, E.J. 1995b. Mating strategy and reproductive success in the teiid lizard, Ameiva plei. Behaviour 132:529-557.

Cooper, W.E., Jr. 1999. Tradeoffs between courtship, fighting, and antipredatory behavior by a lizard, Eumeces laticeps. Behavioral Ecology and Sociobiology 47:54-59.

Costa, H.C., E.T. da Silva, P.S. Campos, M.P. da Cunha Oliveira, A.V. Nuses, and P. da Silva Santos. 2010. The corpse bride: A case of Davian behaviour in the Green Ameiva (Ameiva ameiva) in southeastern Brazil. Herpetology Notes 3:79-83.

Estrada, A.R., J. Novo, and L.V. Moreno. 1987. Datos sobre una puesta de Ameiva auberi Cocteau (Sauria: Teiidae). Miscelanea Zoológica 30:2-3.

Fong, A., D. Maceira, W.S. Alverson, and J.M. Shopland (eds.). 2005. Cuba, Siboney-Juticí. Rapid Biological Inventories Report 10. The Field Museum, Chicago, Illinois.

Gali, F. and O.H. Garrido. 1986. Two new subspecies of Ameiva auberi (Reptilia: Teiidae) from Cuba. Caribbean Journal of Science 22:165-173.

Henderson, R.W. and R. Powell. 2009. Natural History of West Indian Reptiles and Amphibians. University Press of Florida, Gainesville.

Hirth, H.F. 1963. The ecology of two lizards on a tropical beach. Ecological Monographs 33:83-112.

Hower, L.M. and S.B. Hedges, S.B. 2003. Molecular phylogeny and biogeography of West Indian teiid lizards of the genus Ameiva. Caribbean Journal of Science 39:298-306.

Kerr, A.M., R. Powell, and J.S. Parmerlee, Jr. 2005. Ameiva erythrocephala (Teiidae) on Sint Eustatius, Netherlands Antilles: Baseline data on a small population in a severely altered habitat. Caribbean Journal of Science 41:162-169.

Lewis, A.R. 1986. Body size and growth in two populations of the Puerto Rican Ground Lizard (Teiidae). Journal of Herpetology 20:190-195.

Lewis, A.R., G. Tirano, and J. Sepulveda. 2000. Body size and paternity in a teiid lizard (Ameiva exsul). Journal of Herpetology 34:110-120.

Lima, S.L. and L.M. Dill. 1990. Behavioral decisions made under the risk of predation: A review and prospectus. Canadian Journal of Zoology 68:619-640.

Meier, A.J., R.E. Noble, and S.L. Rathbun. 1993. Population status and notes on the biology of the St. Croix Ground Lizard on Green Cay (St. Croix, U.S. Virgin Islands). Caribbean Journal of Science 29:147-152.

Noble, G.K. and H.K. Teale. 1930. The courtship of some iguanid and teiid lizards. Copeia 1930:54-56.

Powell, R and E.J. Censky. 2002. Ameiva alboguttata. Arboreal activity. Herpetological Review 33:50.

Quesnel, V.C. 1978. The reproductive behaviour of the lizard, Ameiva ameiva tobagana. Living World 1978-1979:16-18.

Rodríguez-Ramirez, J. and A.R. Lewis. 1991. Reproduction in the Puerto Rican teiids Ameiva exsul and A. wetmorei. Herpetologica 47:395-403.

Rodríguez-Schettino, L. 2000. Cuban reptiles: Original citations, holotypes and geographic range. Smithsonian Herpetological Information. Service No. 125. Smithsonian Institution, Washington, D.C.

Sampedro, A., V. Berovides, and O. Torres. 1982. Morfometría, alimentación, y actividad de Ameiva auberi (Reptilia: Teiidae) en el sur de la región Oriental de Cuba. Ciencias Biológicas 7:105-112.

Schwartz, A. and R.W. Henderson. 1991. Amphibians and Reptiles of the West Indies: Descriptions, Distributions, and Natural History. University of Florida Press, Gainesville.

Simmons, J.E. 1975. The female reproductive cycle of the teiid lizard Ameiva ameiva petersii. Herpetologica 31:279-282.

Simmons, P.M., B.T. Greene, K.E. Williamson, R. Powell, and J.S. Parmerlee, Jr. 2005. Ecological interactions within a lizard community on Grenada. Herpetologica 61:124-134.

Smith, R.E. 1968. Studies of reproduction in Costa Rican Ameiva festiva and Ameiva quadrilineata (Sauria: Teiidae). Copeia 1968:236-239.

Somma, C.A. and G.R. Brooks. 1976. Reproduction in Anolis oculatus, Ameiva fuscata, and Mabuya mabouya from Dominica. Copeia 1976:249-256.

Sproston, A.L., R.E. Glor, L.M. Hartley, E.J. Censky, R. Powell, and J.S. Parmerlee, Jr. 1999. Niche differences among three sympatric species of Ameiva (Reptilia: Teiidae) on Hispaniola. Journal of Herpetology 33:131-136.

Wolcott, G.N. 1923. The food of Porto Rican lizards. Journal of the Department of Agriculture of Porto Rico 7:5-38. 